\title{
拡張ヒュッケル法による $\mathrm{Al}$ 合金における 固溶性亡化合物形成性の計算
}

\section{山本＼cjkstart悟* 若林利幸*十 小林久芳**}

\author{
*京都大学工学部治金学教室 \\ **京都府立大学生活科学部
}

J. Japan Inst. Metals, Vol. 57, No. 12 (1993), pp. 1367-1373

\section{Calculation of Solid Solubility and Compound Formability of Al Alloys by Extended Hückel Method}

\author{
Satoru Yamamoto*, Toshiyuki Wakabayashi* and Hisayoshi Kobayashi** \\ *Department of Metallurgy, Faculty of Engineering, Kyoto University, Kyoto \\ **Faculty of Living Science, Kyoto Prefectural University, Kyoto
}

In the present work, the solid solubility, formation of compounds and strength in Al alloys have been examined by the calculation of energy and Mulliken's population of cluster models by the extended Hückel method.

The results of the present work are as follows:

(1) The stability of alloy systems and the nature of chemical bonds between the atoms of $\mathrm{Al}$ and the alloying elements can be estimated from the cohesive energy, atomic bond populations and atomic populations.

(2) The tendency of mutual solid solubility, insolubility and compound-formation in Al alloys can be judged as follows:

(a) In the case of the elements which make compounds and have no mutual solubility with $\mathrm{Al}$, the change of cohesive energy with the composition deviates markedly from lineality and the nature of chemical bonds is ionic or covalent.

(b) In the case of the elements which make compounds and have mutual solubility with $\mathrm{Al}$, the change of cohesive energy with the composition deviates a little from lineality and the nature of bonds is a mixture of ionic or covalent and metallic bonds.

(c) In the case of elements which make no compounds and have mutual solubility with $\mathrm{Al}$, the cohesive energy changes linearly with the composition and the nature of bonds is the metallic one or its mixture with covalent or ionic bond.

(d) In the case of elements which make no compounds and have no mutual solubility with Al, the change of cohesive energy with the composition deviates a little from linearlity and the nature of bonds is anti-bonding.

(3) The hardening ability of solute atoms in $\mathrm{Al}$ alloys may be attributed to the (covalent + ionic) part in the nature of chemical bonds between $\mathrm{Al}$ atoms and solute atoms.

(Received June 14, 1993)

Keywords: solid solubility, compounds, extended Hückel method, cohesive energy, Mulliken's population

\section{I．緒言}

マンピューダーの性能の向上が著しく, また種々の計算プロ グラムも開発改良されて，最近は我々の研究に括いても比較的 容易に利用することが可能になってきた。とこで著者等るコン ピューターの計算を金属合金の研究に活用することを試みてき た(1)-(3)，金属合金材料を問題とする限り，合金における固溶， 不溶，化合物形成，強度は最も基本的な問題である.したがっ てその基礎的理解は極めて重要である。そこで，今回は分子軌
道法の一種である搪張上ュッタル法を用いて，クラスターモデ ルの凝集エネルギーおよび Mullikenの各種 population を計算

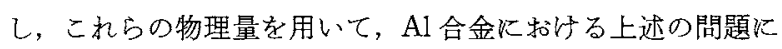
ついて検討したのでその結果を報告したい，

\section{II. 計 算 方 法}

1. 拡張ヒュッケル法について

本計算法については，既にいくつもの優れた成書(4)(5)があ る、さらにこの訪算法の特徴については前報(1)-(3)で述べたの で，詳しくはそれらを参考にしていたださたい。 
搪張七ェッケル法は, パラメータとして軌道指数 ${ }^{(6)-(8)}$ (orbital exponent) とイオン化ポテンシャル(9)-(11)が与兄られるば 分子軌道 $(\mathrm{MO})$, 軌道エネルギー, 全エネルギ一さらに各種の population などが計算できる. 全エネルギーから凝集エネルギ 一を求めることができ，これで安定性を評価することができる。 Mullikenの populationからは電子の分布を知ることができ る、凝集エネルギーの大小と, Mullikenの population とを組 合せると結合性を判定することがでさる，そこで，本研究では これらの判定結果に基ついて $\mathrm{Al}$ 合金に抬ける固溶, 不溶, 化 合物形成の問題および強度の問題を検討した。

\section{2. モデル作成について}

$\mathrm{Al}$ 合金に敌ける固溶性，不溶性，化合物形成性を検討する 本研究に乱いてはつぎのようなクラスターモデルを採用した。 まず第一に，表面原子の影響を少なくするため，コンピュータ 計算上可能なかぎり原子数を多くし，かつ球形に近いクラスタ 一を用い，その大ささはそれぞれの構造ごとに一定とした。す なわち，面心立方格子に扎い，中心原子から第 4 近接原子 までをとり，全原子数55個の一定の大きさの球形に近いクラ スターとした。実際什匴に用いた $\mathrm{Al} の$ 結晶構造牤よび格子 定数は室温近傍のそれである(12)。第二に，凝集エネルギーの 合金元素々その組成による変化を調べるために，Al 原子をラ ンダムにつぎつぎに合金元素で置換して凝集エネルギーを計算

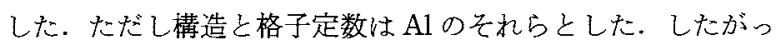
て，合金元素とその組成が変化すると，実際仙構造と格子定 数が変化するにもかかわらず，第一近似として，それらを無視 した仮想的な系について計算したことになる. Mullikenの populationの評価に際しては，55個の $\mathrm{Al}$ 原子の球形クラスタ 一の中心原子 1 個のみを合金元素で置き換光，その中心原子 と第一近接 $\mathrm{Al}$ 原子执よびそれらの間の populationを採用 L ז.

\section{III. 計 算 結 果}

\section{1. 疑集エネルギーについて}

凝集エネルギーの計算結果をFig. 1 火示す。凝集エネルギ 一は，クラスターを構成する原子が互いに無限に遠く離れてい る状態を基集(エネルギーゼロ)にし，そこから凝集してクラス ターを形成した時のエネルギーの低下量を表すおのとし，正で 大きい值活ど安定となるようにしたが，本研究ではとの絁対值 ではなく，その相対的変化量が重要なので，Fig. 1 の左端の純 $\mathrm{Al}$ の凝集エネルギーの計算值が実験值に合致するように多少 補正した結果が示してある。すなわち，実際の結晶構造と格子 定数をとるときに紏 $\mathrm{Al}$ の凝集エネルギーの計算值が実測値に 一致するように，Alの孤立原子のエネルギーを補正した。そ の補正量は $0.6 \mathrm{aJ}$ である．右端には合金元素の紏物質の凝集 エネルギーの実測值が記号で示してある. 図が複雑になるのを 避けるため，両端の純物質の凝集エネルギーを結んだ基線は実 際には省略してあるが，そのような基線を想定して計算結果を 見ると便利である。凝集エネルギーがその上らな仮想的な基線 に沿って变化すれば，合金の凝集エネルギーが構成純物質の凝 集エネルギーの組成平均で与兄られることを意味する。これら
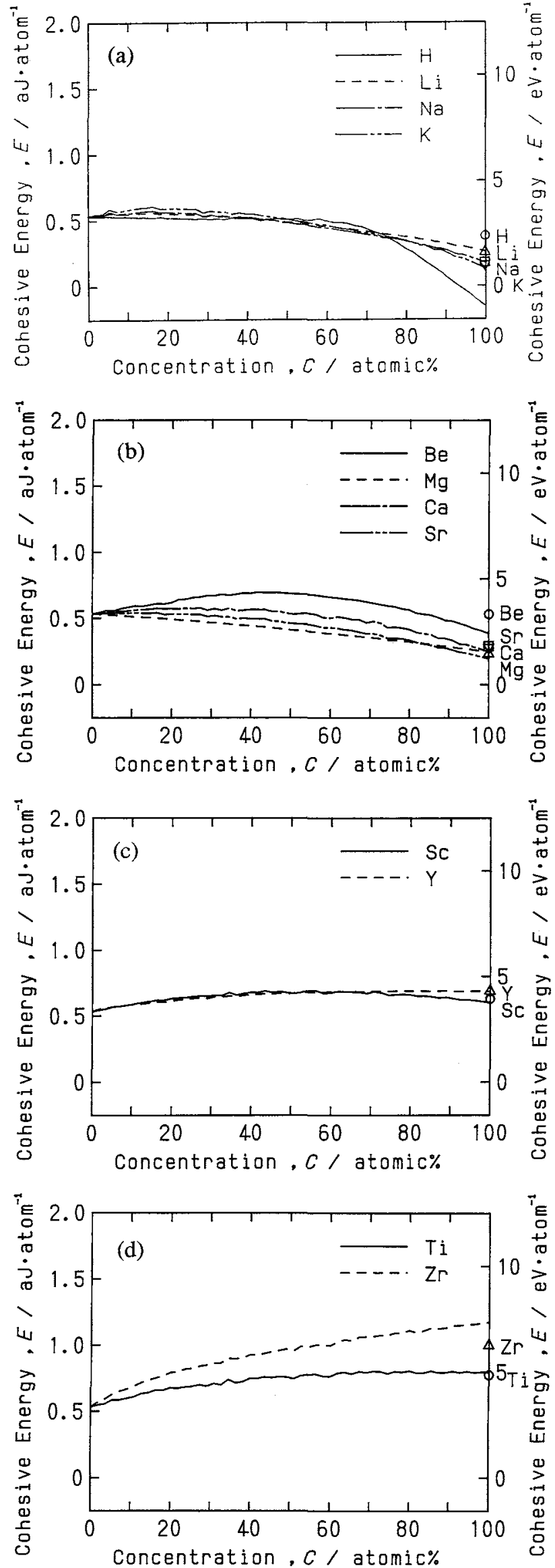

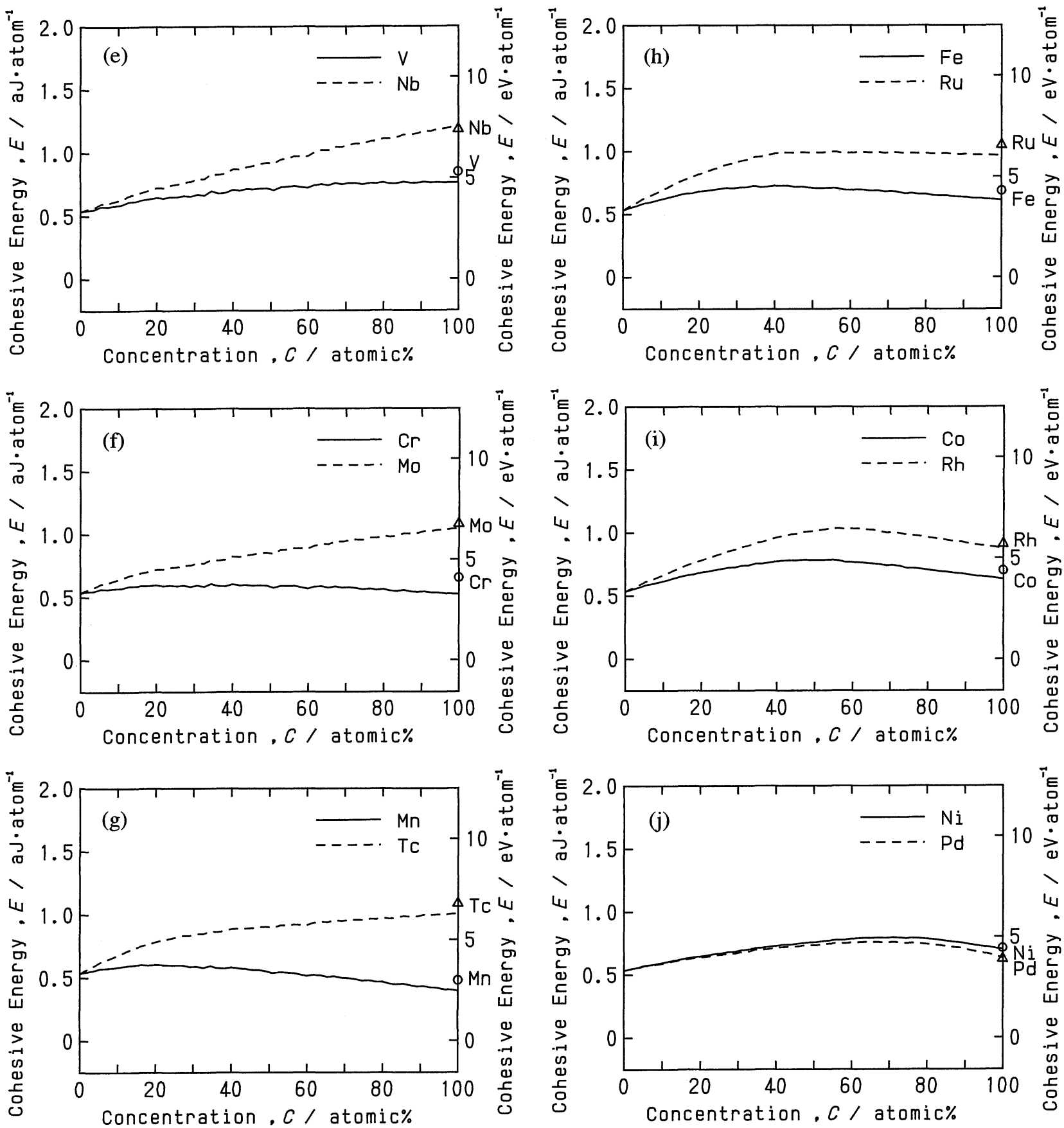

Fig. 1 (a) Change of cohesive energy of $\mathrm{Al}-\mathrm{H},-\mathrm{Li},-\mathrm{Na}$ and $-\mathrm{K}$ binary alloys. (b) Change of cohesive energy of $\mathrm{Al}-\mathrm{Be},-\mathrm{Mg}$, -Ca and -Sr binary alloys. (c) Change of cohesive energy of Al-Sc and - Y binary alloys. (d) Change of cohesive energy of Al$\mathrm{Ti}$ and $\mathrm{Zr}$ binary alloys. (e) Change of cohesive energy of Al- $\mathrm{V}$ and - $\mathrm{Nb}$ binary alloys. (f) Change of cohesive energy of $\mathrm{Al}-$ $\mathrm{Cr}$ and -Mo binary alloys. (g) Change of cohesive energy of Al-Mn and -Tc binary alloys. (h) Change of cohesive energy of $\mathrm{Al}-\mathrm{Fe}$ and -Ru binary alloys. (i) Change of cohesive energy of Al-Co and - Rh binary alloys. (j) Change of cohesive energy of Al-Ni and -Pd binary alloys. (k) Change of cohesive energy of Al-Cu and - Ag binary alloys. (l) Change of cohesive energy of $\mathrm{Al}-\mathrm{Zn}$ and $-\mathrm{Cd}$ binary alloys. (m) Change of cohesive energy of Al-B, -Ga and -In binary alloys. ( $\mathrm{n}$ ) Change of cohesive energy of $\mathrm{Al}-\mathrm{C},-\mathrm{Si}$,-Ge and -Sn binary alloys. (o) Change of cohesive energy of Al-N, -P and -As binary alloys. (p) Change of cohesive energy of Al-O, $-\mathrm{S}$ and -Se binary alloys. (q) Change of cohesive energy of $\mathrm{Al}-\mathrm{F},-\mathrm{Cl}$ and $-\mathrm{Br}$ binary alloys.

の凝集エネルギーの計算結果から, 安定性を判定することがで きる.すなわち，仮想基線から大きく正に偏倚するほど，クラ スターが安定であることを意味する．例えば， C, N , O , F など は，それぞれ Fig. 1(n)，(o)，(p)，(q)から，その凝集エネルギ
一変化は仮想基線から大きく正に偏倚し，大きな凝集エネルギ 一をもっているが，これはこれらの元素が $\mathrm{Al}$ との間に安定な 化合物を形成することに対応する. また右端で凝集エネルギー が純物質のそれよりも下になっているものがあるのは, 既に述 

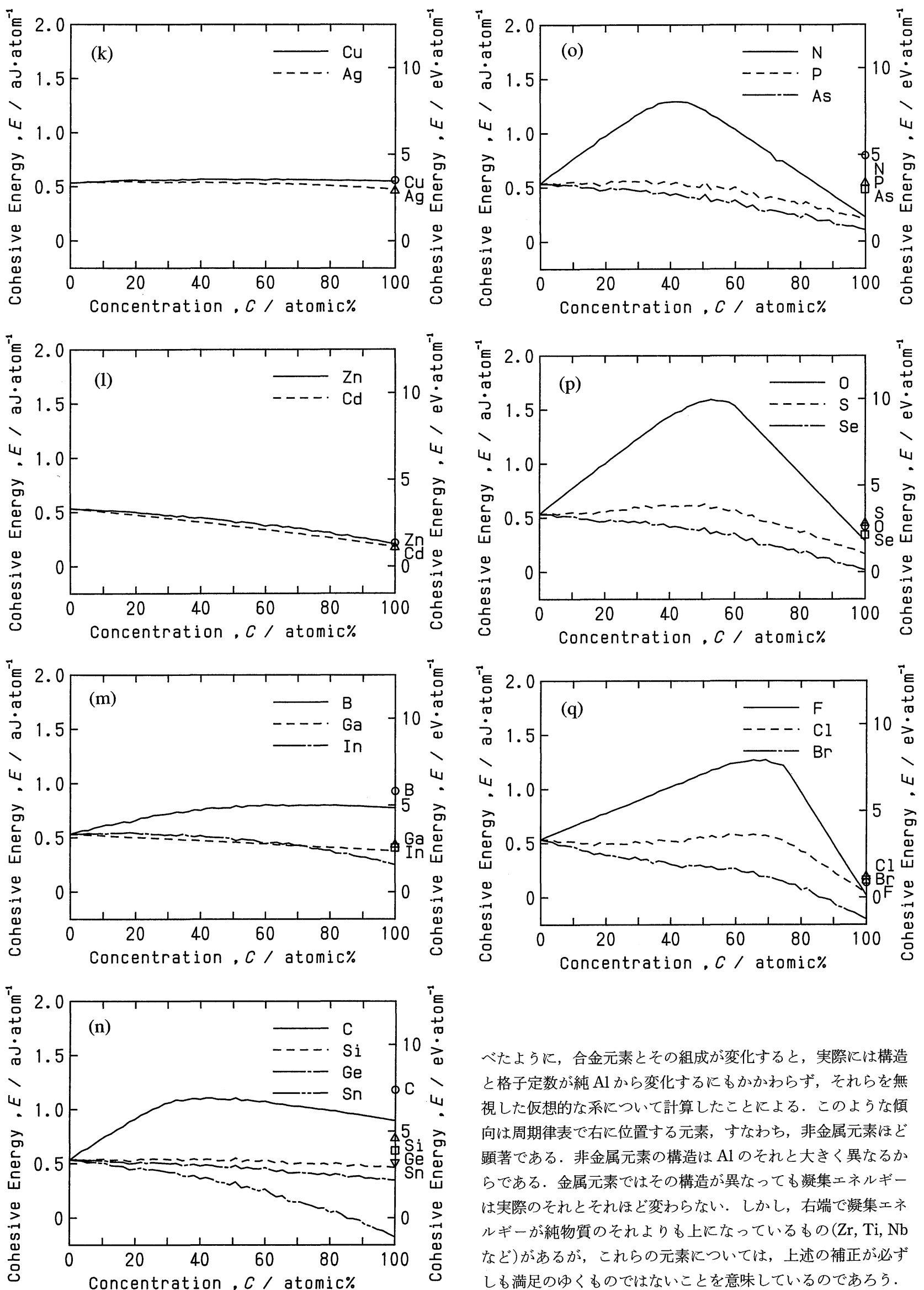

べたように，合金元素とその組成が変化すると，実際には構造 と格子定数が純 $\mathrm{Al}$ から変化するにもかかわらず，それらを無 視した仮想的な系について計算したことによる.このよらな傾 向は周期律表で右に位置する元素, すなわち, 非金属元素注ど 顕著である. 非金属元素の構造は $\mathrm{Al}$ のそれと大きく異なるか らである．金属元素ではその構造が異なっても凝集エネルギー は実際のそれとそれ汪ど変わらない. しかし, 右端で凝集エネ ルギーが純物質のそれよりも上になっているもの $(\mathrm{Zr}, \mathrm{Ti}, \mathrm{Nb}$ など)があるが，これらの元素については，上述の補正が必ず しも満足のゆくものではないことを意味しているのであろう. 


\section{Mulliken の各種 population について}

Mulliken の各種 population の計算結果をFig. 2 に示す. atomic population はその原子に所属する電子数を岁らわすが,

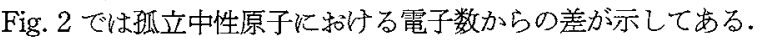
Alの atomic population が負になっているのは, 電気の良導体 では，電荷が中心から表面に移動する傾向を反映したるのであ る. atomic population が Alより小さい元素は, アルカリ金 属，アルカリ土類金属であり，それ以外の汪とんどの元素では atomic population が $\mathrm{Al}$ より大きくなっているが，これらは Paulingの電気陰性度の大小に良く対応している。

atomic bond population は，化学に批ける公統的な概念であ る結合次数を Mulliken が拡張したるのである。この大小によ って，共有結合性の強さを判定でさる，前節で述べた凝集エネ ルギーの大小にこれらの Mullikenの populationを組合せる と，原子間の局所的な結合性をすあるせ判定することがでさ る. その判定法は次のようなるのである。

まず，凝集エネルギーの比較的大きな四種類の結合は次の上 らに判定できる。

共有結合性; atomic bond populationが正で大かつ atomic population が中性

金属結合性; atomic bond population が正で小かつ atomic population が中性

静電結合性; atomic bond populationがゼロないし負かつ atomic population が正と負

分子結合性 ; atomic bond population がゼロかつ atomic population $か ゙$ 中性

さらに,

反結合性; atomic bond population が負かつ atomic population がゅ性

最後の反結合性の凝集エネルギーはもらろん負あるいは岋口で ある.現実にはこのよらに理想的な結合は存在せず，これらの 結合性の混じったものとなる。例えば， C, N , O , F, Cl などは それぞれ Fig. 1(n)，(o)，(p)，(q)から凝集エネルギーが大であ りまた Fig. 2(a)，(b)から， atomic population が正の大きな
值かつ atomic bond population が負の值をもっていることが かかる.したがって，こ机らの元素は $\mathrm{Al}$ との間に静電結合を 作ることがわかる。李た K, Na は，Fig. 1(a)から凝集エネル ギーが小さく, Fig. 2(b)から atomic bond population が負の 值をっていることがわかる。したがって，これらの元素と $\mathrm{Al}$ との間の結合は反結合的であることがわかる. $\mathrm{Ga}, \mathrm{Si}, \mathrm{Ge}$, Sn, Asなどは, Fig. 2(a)，(b)から, atomic population が中性 かつ atomic bond population が大であるから，共有結合性で ある.その他の元素は atomic population が正かつ atomic bond population が正であることから，それらの結合性は共有 (金属)結合性と静電結合性との共鳰状態にあることがわかる.

\section{N. 考察}

本研究の計算結果を用いると，以下に述べるよら飞，Al の諾元素の固溶, 不溶, 化合物形成問題や強度問題について検 討でさる。

1. Al 合金における固溶性，不溶性，化合物形成性につい $\tau$

$\mathrm{Al}$ 合金の固溶性，不溶性，化合物形成性についての実験事 実(13)(14) は次の上らである.A1 を溶媒とした場合，これに溶 質としてょく溶ける元素は， $\mathrm{Zn}(66.5 \%), \mathrm{Ag}(25.8 \%)$, $\mathrm{Mg}(18.9 \%), \mathrm{Li}(14.9 \%), \mathrm{Ga}(8 \%), \mathrm{Be}(2.9 \%), \mathrm{Ge}(2.8 \%)$, $\mathrm{Cu}(2.5 \%), \mathrm{Si}(1.6 \%), \mathrm{Mn}(0.7 \%), \mathrm{Cd}(0.1 \%), \mathrm{Au}(0.04 \%)$ (括 弧内最大固溶量をat\%で示したもの)などである. その他の 元素は汪とんど固溶しない，逆に $\mathrm{Al}$ が溶質としてよく溶け迅 んでいく元素としては， $\mathrm{Fe}(54 \%) ， \mathrm{~V}(51 \%) ， \mathrm{Ti}(48.5 \%)$ ， $\mathrm{Mn}(44 \%), \quad \mathrm{Cr}(27 \%), \quad \mathrm{Zr}(26 \%), \quad \mathrm{Ni}(21 \%), \quad \mathrm{Ag}(19.9 \%)$, $\mathrm{Cu}(19.6 \%), \mathrm{Mo}(19.5 \%), \mathrm{Pd}(18 \%), \mathrm{Co}(16 \%), \mathrm{Mg}(11.6 \%) な$ どがある. Al と化合物を形成しやすい元素は， $\mathrm{O}, \mathrm{S}, \mathrm{Se}, \mathrm{Te}$, $\mathrm{N}, \mathrm{P}, \mathrm{As}, \mathrm{Sb}, \mathrm{F}, \mathrm{Cl}, \mathrm{Br}, \mathrm{C}, \mathrm{Li}, \mathrm{Ca}, \mathrm{Co}, \mathrm{Ni}, \mathrm{Pd}, \mathrm{Fe}, \mathrm{Cr}, \mathrm{Mo}, \mathrm{V}, \mathrm{Nb}$, $\mathrm{Ti}, \mathrm{Zr}, \mathrm{Cu}, \mathrm{H}$ などである。このような実験事実を考慮すると， これらの元素はまず，次のよらに 4 種類に分類することがで きょう.
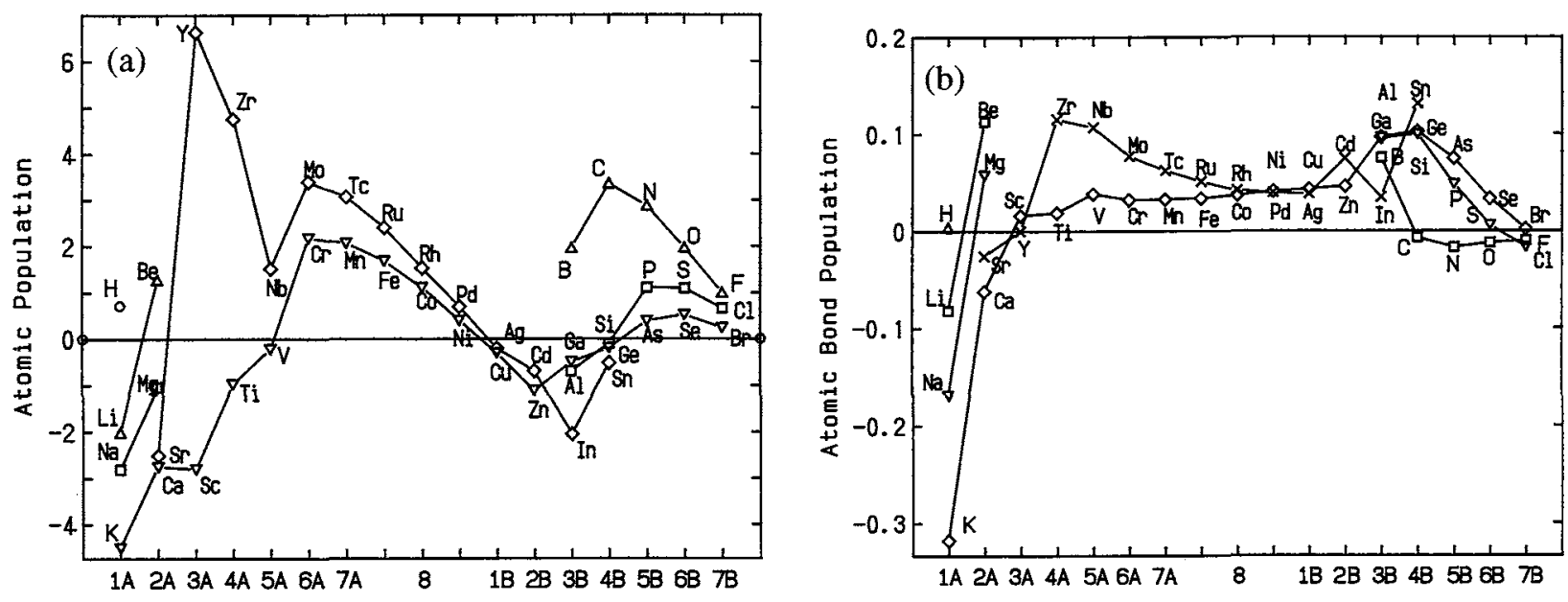

Fig. 2 (a) Atomic population in $\mathrm{Al}_{54} \mathrm{X}_{1}$ cluster. (b) Atomic bond population in $\mathrm{Al}_{54} \mathrm{X}_{1}$ cluster. 
（1） Al 原子と化合物を作るのみで相互固溶性を示さない元 素

（2） $\mathrm{Al}$ 原子と化合物を作るが相互固溶性を示す元素

（3） $\mathrm{Al}$ 原子と化合物を作らず，相互固溶性のみを示す元素

（4） Al 原子と化合物を作らず，相互固溶性も示さない元素

さて, 任意の元素がこれら 4 種類のどれに属するかは, 凝 集エネルギー变化(Fig. 1(a) から(q)) か Mullikenの population (Fig. 2(a) と(b))のどちらか片方だけでは判別できない が，これらを組合せると判別できる．特に，Al 合金だけに限 定すれば, population だけであある程度判別できる.すなわち, atomic bond population と atomic population とを使って,

Fig. 3 のように整理すると, 2 本の水平線と 2 本の垂直線に よって大体区分されることからわかるように，同じ型に属する 元素同士は群れをなしてかたまることがわかる．Al より atomic bond population が遥に小さい元素は，不溶元素となり，左 下に集まる。 Al より atomic bond population がやや小さい元 素は, $\mathrm{Al}$ との atomic population の差が大きい場合のみ，化合 物を形成する. $\mathrm{Al}$ と atomic bond population が似た元素の挙 動は sp 電子系と sd 電子系とで異なる. 固溶型の元素は $\mathrm{Al}$ と の atomic population の差が小さな sp 電子系に限定されるよ らである. atomic population の差が大きくなると化合物を形 成する傾向がでてくる. こうして, 次のようにまとめられる.

（1） Al 原子と化合物を作るのみで相互固溶性を示さない元 素は，(a)凝集エネルギーの組成変化が直線から大きく偏倚，(b) 結合性は静電結合か共有結合, (c) C, N, P, As, O, S, Se, F, Cl, $\mathrm{Br}, \mathrm{H}, \mathrm{Ca}, \mathrm{Sr}$ などが属する.

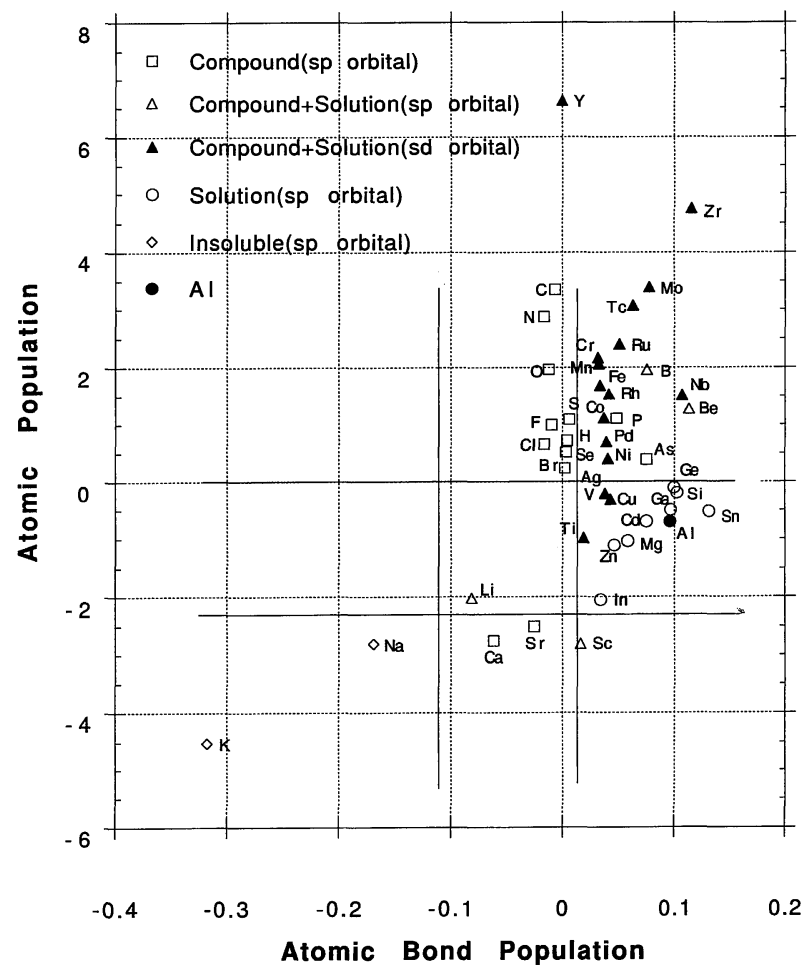

Fig. 3 Classification of solute atoms based upon Mulliken's population.
（2） $\mathrm{Al}$ 原子と化合物を作るが相互固溶性を示す元素は，(a) 凝集エネルギーの組成変化が直線からやや偏倚, (b)結合性は (静電結合十共有結合性) 飞金属結合性の加わったもの，(c) Li, $\mathrm{Be}, \mathrm{B}, \mathrm{Sc}, \mathrm{Y}, \mathrm{Ti}, \mathrm{Zr}, \mathrm{V}, \mathrm{Nb}, \mathrm{Cr}, \mathrm{Mo}, \mathrm{Mn}, \mathrm{Tc}, \mathrm{Fe}, \mathrm{Ru}, \mathrm{Co}, \mathrm{Rh}$, $\mathrm{Ni}, \mathrm{Pd}, \mathrm{Cu}, \mathrm{Ag}$ などが属する.

（3） Al 原子と化合物を作らず，相互固溶性のみを示す元素 は, (a)凝集エネルギーの組成変化が直線的, (b)結合性は金属結 合かこれに共有結合あるいは静電結合の加わったもの，(c) $\mathrm{Mg}, \mathrm{Zn}, \mathrm{Cd}, \mathrm{Ga}, \mathrm{In}, \mathrm{Si}, \mathrm{Ge}, \mathrm{Sn}$ などが属する.

（4） Al 原子と化合物を作らず, 相互固溶性も示さない元素 は, (a)凝集エネルギーの組成変化が直線から偏倚, (b)結合性は 反結合性, (c) $\mathrm{Na}, \mathrm{K}$ などが属する.

従来, これらの事実を理解する過去の理論的な試みとして は, まず, 合金の固溶性, 不溶性に関しては, Hume Rothery の法則や森永等(15)の $\mathrm{Md}$ 值 ( $\mathrm{d}$ 電子の占める分子軌道のもつエ ネルギーを組成で平均した值)による固溶限の評価などがある. 化合物形成傾向については, Hume Rothery や Pauling による 共有結合やこれへの静電結合共鳴の理論がある. これらは, 固 溶性については, それぞれ原子半径差と軌道エネルギー, 化合 物形成については, 共有原子価, 電気陰性度を用いて, 検討し たものである. 本研究は, 固溶性, 化合物形成性の検討に, 凝 集エネルギーと Mullikenの population とを用いた. 固溶性, 化合物形成性を全面的包括的に理解するにはこのよらにいろい ろな物理量を基にして検討する必要があり,それらは互いに相 補的な視点を提供するすのであろう。

\section{2. $\mathrm{Al}$ 合金の固溶体強度}

まず，固溶体硬化についての実験事実(14)(16) としては，Al に固溶した場合, 硬化能を持つ元素は, $\mathrm{Cu}, \mathrm{Mg}, \mathrm{Zn}, \mathrm{Si}, \mathrm{Li}$ な ぞである.

これらの事実は，どのよらに理解できるであろうか？固溶 した場合に合金元素の示す硬化能と結合性との関係は，結合の 本性から, その結合性が, 共有結合性 (周期律表で短周期の元 素や $\mathrm{N}, \mathrm{V}, \mathrm{V}$ 族の元素は共有結合性が大), 共有結合性+静 電結合性であれば, 硬化能は大であり, 結合性が金属結合性, 分子結合性であれば, 硬化能は小であると推定されようが，実 際の結果も大体そのようになっている。すなわち，上述の $\mathrm{Al}$ 中の固溶元素は, atomic bond population が比較的大かつ atomic population も比較的大(共有結合性十静電結合性)であ ることによって硬化能が大なのである．つまり硬化能をるつ合 金元素はその合金の基調となる金属結合性に共有結合性や静電 結合性を付加する元素である.

\section{V. 総 括}

本研究では, 分子軌道法の一種である拡張ヒュッケル法を用 いて，クラスターモデルの凝集エネルギー扣よび Mullikenの 各種 population を計算し，これらを用いて， $\mathrm{Al}$ 合金に拈ける 固溶性，不溶性，化合物形成性と強度について検討した．その 結果,

（1）凝集エネルギーの大小で安定性を判定することができ， これにさらに atomic bond population と atomic population と 
を組合せると $\mathrm{Al}$ 原子と溶質原子との間の結合性(すなわち， 共有結合，金属結合，静電結合，分子結合)を判定することが できる。

（2） Al 合金に批る合金元素の不溶性，固溶性，化合物形 成性傾向は次のように判定することができる。すなわち，

(a) A1 原子と化合物を作るの及で相互固溶性を示さない 元素は，凝集エネルギーの組成变化が直線から大き偏倚, 結合性は静電結合か共有結合である。

(b) A1 原子と化合物を作るが相互固溶性を示す元素は， 凝集エネルギーの組成変化が直線からやや偏倚, 結合性は (静電結合十共有結合)に金属結合の加わったものである.

(c) A1 原子と化合物を作らず，相互固溶性の及を示す元 素は，凝集エネルギーの組成变化が直線的，結合性は金属結 合かこれに共有結合あるいは静電結合の加わったるのであ る.

（d）A1 原子と化合物を作らず，相互固溶性も示さない元 素は, 凝集エネルギーの組成变化が直線から偏倚, 結合性は 反結合性である。

（3） Al 合金に和ける溶質元素の硬化能は A1 原子々溶質原子 の間の結合性の共有結合性と静電結合性の部分に起因する.

\section{文献}

（1）山本 悟, 小林久芳, 井/山直哉：物, 64(1992), 107.

（2）井，山直载，山本 悟，川野 豊：反応論からみた鏻 鉄，新日本鋳䥀造協会，(1992), 45.

（3）山本悟，水野正隆，小林久芳：日本金属学会誌 $\mathbf{5 7}(\mathbf{1 9 9 3 )}, 402$

（4）米澤貞次郎，永田親義：三訂量子化学入門(上)（下）, 化学同人, (1983), 83, 349 .

（5）時田澄男，富永信秀：BASIC Kよる分子軌道計算入門， 共立出版, (1987), 1 .

(6) E. Clementi and D. L. Raimondi: J. Chem. Phys. $38(1963), 2686$

(7) J. W. Richardson, W. C. Nieuwpoort, R. R. Powell and W. F. Edgell: J. Chem. Phys., 36(1962), 1057.

(8) E. Clementi, D. L. Raimondi and W. P. Reinhardt: J. Chem. Phys., 47(1968), 1300.

(9) H. Basch and H. B. Gray: Theoret. Chim. Acta, 4 (1966), 367.

(10) H. Basch, A. Viste and H. B. Gray: Theoret. Chim. Acta, 3 (1965), 458.

(11) C. J. Ballhausen and H. B. Gray: Moleculer Orbital Theory, Benjamin, Inc., New York, (1965), 92.

（12）日本金属学会編：金属データブック，丸善, (1974), 42 .

(13) Max Hansen: Constitution of binary alloys-Metallurgy and metallurgical engineering series, McGraw-Hill, (1958).

(14) L. F. Mondolfo: Aluminium Alloys: Structure and Properties, Butterworths, (1976), 68, 213.

(15) M. Morinaga, N. Yukawa, H. Ezaki and H. Adachi: Phil. Mag., A, 51(1985), 223.

（16）アルミニウムハンドブック，住友軽金属，(1978), 26 